\title{
設計空間としてのVRにおける状況との対話のプロセス \\ A PROCESS OF DIALOGUE WITH SITUATION IN VR AS A DESIGN SPACE
}

\author{
四宮駿 介*1, 酒谷粋将*2, 田中義之*3, 千葉学*4 \\ Shunsuke SHINOMIYA, Suisho SAKATANI, Yoshiyuki TANAKA \\ and Manabu CHIBA
}

\begin{abstract}
This paper aims to characterize non-expert design thinking in a VR environment, and to achieve it, we built a system that enables design by dialogue in VR space and conducted design experiments. We presented a model of the design space in VR space, and through the analysis of the situation and objects perceived by the subject in the VR space, we presented the possibility of a design process carried out through multifaceted evaluation and efficient iterations. Furthermore, we extended the model to include other subjects and presented the possibility of a design process through object-mediated dialogue between the subjects.
\end{abstract}

Keywords: collaboration, VR, dialogue, design space, design process コラボレーション, VR, 対話, 設計空間, 設計プロセス

\section{1.はじめに}

\section{1 研究の背景と目的}

近年、空き家や空きビルの問題が顕在化し、その活用の必要性が 叫ばれ、リノベーションや DIY 等によって空間が再生される事例も 多く現れてきている。そうした建築プロジェクトの設計段階では、 既存ストックを対象とするがゆ光の個別の条件が多く、設計主体は 設計を進めながら既存の空間の価值を探究するプロセスをたどるこ とになる。時にはその中で空間の新しい用途や活用のアイデアも生 まれるのであるが、建築の企画や計画が設計に先立つ一般的な建築 プロセスに沿ってしまうと、そうした設計プロセスの中で見出され た空間の利活用のアイデアを十分に活かすことは難しく、その可能 性を最大限に広げていくためには、企画や計画の段階と一体的に設 計のプロセスを捉える必要があるだろう。そして建築プロセスの重 要な意思決定の主体となるユーザーやクライアントにその設計へと いかに深く関わってもらえるかが重要になってくるものと思われる。

一方、情報空間の中に 3 次元空間を構築し、その体験を可能にす るVR（Virtual Reality）の技術が近年注目を集め、建築分野でも空 間の体験を通した設計の評価ツールとして活用される場面が多くな ってきている。こうした技術によって従来であれば図面や模型等の ッールを用いて設計対象にあらゆる検討を加えていた設計行為の手 続きが拡張され、設計に並行して変化を続ける設計対象の空間を逐 次体験しながら、設計についての思考を巡らせることが可能になっ てきている。これにより建築家が持つ 3 次元空間を扱う専門的技能 を持たない人々でも眼前には実在しない空間の豊かなイメージを体
験することを通して設計行為に深く関わることが期待できるだろう。 本研究ではより良い設計の可能性、すなわち設計解を探究する空 間を設計空間と呼ぶことにするが、上述の通り設計対象のバーチャ ルな建築空間そのものを設計空間とすることができるVR の特性に 着目し、そうした環境の中でのユーザーやクライアント等の非専門 家による設計思考の特徵を明らかにすることを目指す。更にそうし た VR の設計空間を共有する複数主体の対話のプロセスがどのよう に展開されるのかを捉えることを目的とする。

\section{2 研究の方法}

本研究では上記の目的のもとで、まずはVR の技術を活用した設 計空間のシステムを構築する。具体的には複数の主体が設計対象の 空間をより現実に近い感覚で体験し、その空間内に様々な操作を加 えながら設計案を検討する設計ツールを作成する。今回はその実装 にあたり、ソフトウェアとしてはゲームエンジンである「Unreal Engine 4」（以下、UE4）を、ハードウェアとしては設計ツールとし て利用する際の導入の容易さと機動性に鑑み、スタンドアローン型 HMD (Head Mounted Display) 注1)である Oculus Go を用いる。次 に建築のユーザーやクライアントを想定した建築等の設計の経験を 持たない非専門家を対象とした設計実験を行い、設計中に被験者ら によって交わされる対話のプロセスの分析を行う。ここでは特に 2 章で述べる「状況論的アプローチ」に着目し、状況に埋め込まれた 行為としての設計が VR 空間の中でどのように展開されるのかを明 らかにする。そして最後に本研究の結論を述べ、研究の成果を踏ま えた今後の設計ツールの開発や発展の可能性について述べる。
SUPPOSE DESIGN OFFICE (侏) 修士（工学）

関東学院大学建築・環境学部建築・環境学科 専任講師・博士 (工学)

3 東京大学大学院工学系研究科建築学専攻 助教・修士 (環境学)

東京大学大学院工学系研究科建築学専攻 教授·工修
SUPPOSE DESIGN OFFICE Co, Ltd, MEng.

Lect., Dept. of Architecture and Environmental Design, College of Architecture and Environmental Design, Kanto Gakuin University, Dr.Eng.

Assist. Prof., Dept. of Architecture, Faculty of Engineering, The University of Tokyo, M.Env.

Prof., Dept. of Architecture, Faculty of Engineering, The University of Tokyo, M.Eng. 


\section{3 既往研究と本研究の位置づけ}

近年では技術の進歩や関連機器の低廉化等により、VR を設計プ ロセスに導入するための研究や実践の事例も増えてきている。例え ば、福田ら ${ }^{1)}$ は分散同期型環境において参加主体が非没入型 VR ア プリケーションを通して景観街づくりの会議を行うシステムを構築 し、実際の景観まちづくりでの使用可能性についてアンケートで高 い評価を得た。このような設計の評価ツールとしての利用に対して、 設計プロセスの初期段階における有用性を検証した研究も多い。

F.P.Rahimian $~^{2)}$ は、従来型の紙やペン等を用いたスケッチによる 設計プロセスと非没入型 VRソフトを使用した設計プロセスの比較 による設計実験とプロトコル分析を行い、非没入型 VR システムに おいては設計者らの協同的行為のパフォーマンスが改善されるとと もに、システムを通して得た予期せ好発見を起点にしてょり発展的 な設計の問題空間へと思考が拡がる可能性があることを示した。ま た、V.Rieuf ら ${ }^{3)}$ は工業デザインの初期段階に没入型 VR 環境が及ぼ す影響を明らかにするため、2D 環境と没入型 VR 環境における一 連の設計プロセスを比較する設計実験を行った。その設計プロセス の分析を通して、没入型 VR 環境で設計を行った被験者がスケッチ に取り組む時間を減らし、コンセプト生成のためのインスピレーシ ヨンや設計対象の観察により多くの時間を費やすことを示した。

一方、P. Koutsabasi ら ${ }^{4)}$ は参加による設計の観点から、デザイナ 一とクライアントが協同でデザインを行う VW(Virtual world) と呼 ばれる非没入型 VR 環境のシステムを構築し、それを用いた空間設 計や情報通信端末のユーザーインターフェース設計のケーススタデ イを行った。構築された環境においては被験者らの言語によるコミ ユニケーションの向上に留まらず、物を指し示す等の非言語的なコ ミュニケーションも確認され、ユーザーと設計者の対話における非 没入型 VR 環境の可能性を示した。また、ユーザー参加型の設計プ ロセスにおける没入型 VR の活用に注目した石田ら ${ }^{5)}$ は、HMD を 用いた設計ツールによる設計者・施主を想定した学生ペアの設計実 験を通して、身体の感覚を介した空間の理解や空間における移動に よって空間そのものに加え、空間同士の関係性等のより高次の認識 が非専門家でも行いやすくなることを示した。

設計主体同士の対話だけでなく、設計対象との対話に着目した例 としては、J. H. Israel ら ${ }^{6)}$ の研究がある。この研究では、没入型 VR である CAVE において家具デザイナーを対象とした家具デザイン の実験を行い、被験者らがスケッチした椅子に座ったり、カウンタ 一バーの中を歩いたりと、設計対象とのインタラクティブな行為を より多く示したことを指摘した。

以上のような既往研究に対して、ユーザーやクライアントといっ た非専門家が主体となり、互いに対話を重ねて協同的に、設計対象 に積極的に操作を加えながら設計内容を検討する没入型 VRッール を実装することで、空間の情報を一方向的に享受するだけではない、 よりインタラクティブな対話が可能な設計空間の構築を試み、そう した環境が設計のプロセスに与える影響について明らかにしょうと する点に本研究の特徴があると考える。

\section{2. ユーザー主体による設計のための設計空間}

\section{1 ユーザー主体による設計のプロセス}

本研究では、VR 空間においてユーザーやクライアントが主体と
なって設計を行うような設計空間の可能性について論じるのである が、ユーザーやクライアントが設計行為に関わる試みについてはこ れまでにも多くの研究や実践が行われてきた。その最初期の試みは 「参加による設計」(participatory design) と呼ばれ、1970 年代ごろ から盛んになり始めた。例えば C. Alexander ${ }^{7)}$ はパタンランゲージ を介して住民をはじめとする多くの主体がそのプロセスに関わる参 加型のデザインの在り方を示したし、H. Sanoff $\left.{ }^{8}\right)$ は「デザインゲー ム」(design game)によって、計画や設計に住民が参加しやすくなる しかけを提供し、公園・建築のプランニングを通して、人々のコミ ユニティ活動の原動力を生み出していくことを目指した。

一方で近年の複雑化したプログラムの建築や既存ストックの利活 用等、個別の条件が多く既存の空間の潜在的な価值の発見が求めら れる場合には、ユーザーやクライアントによる設計対象についての 深い理解や、より本質的なレベルでの設計プロセスへの関わり方を 目指さなくてはならないだろう。その実現のためには、従来の参加 による設計の次元を超え、ユーザーが主体となって設計に携わるこ とのできる手立てが求められる。

そこで本研究ではユーザー主体の対話による設計のプロセスの可 能性を探るべく、本来であれば設計の専門家が中心となって扱う空 間の諸要素の操作をユーザー自身が行えるように支援するツールの 構築を目指すのであるが、ここでは特に次節で述べる「状況」の概 念をとおして捉えられるVRの特性に着目する。

\section{2 設計行為の状況論的アプローチ}

D.A. Schön ${ }^{9}$ は、そのままでは意味をなさない不確かな状況に一 定の枠組みを与えることによって問題設定を行うことが重要である とし、優れた専門家は自身の行為の中で省察を行いながら多くのこ とを認識し、次なる行為を判断する「行為の中の省察 (reflection in action)」を行っていることを指摘した。このように枠組みの設定を 繰り返しながら、「状況との対話」を重䄈る設計行為の在り方を示し たのであるが、このことを踏まえ門内 ${ }^{10)}$ は認知科学の分野で着目さ れている「状況論」(situation theory)の観点から設計行為について の考察を行っており、特定の状況の中で分かちがたく結びつく知識 と行為の在り方を前提とする状況論的な視点からショーンの言う行 為の中の省察としての設計行為を捉え直した。この状況論的アプロ 一チに基づく研究としてはヒューマンコンピュータインタラクショ ン(HCI)の研究者である L.A.Suchman ${ }^{11}$ による「状況に埋め込まれ た行為」についての研究が有名である。彼女はヨーロッパ人とトラ ック島民の航海術の比較を引き合いに出し、前者が航海のための普 遍的な原理から構築されたプランに基づく方法であるのに対し、後 者が定めた目的の達成の過程で生じる不測の諸条件にアドホックに 対応する状況に依存した方法であることを明らかにし、完全な予想 が不可能な状況に対応する上ではそうした状況的行為の視点が重要 になることを指摘している。

設計者にとって、建築の図面や模型等を介して空間の像を捉え、 そこに生じる状況を想像することは重要な専門的技能の一つと言え るが、そうした既存の設計の道具を介さずにダイナミックに設計対 象の空間やその状況を捉えることができるという点において、VR を用いて構築する設計空間の可能性があると考える。

\section{3 対話の場としての VR の設計空間モデル}

ここで 5 章と 6 章における設計プロセスの分析に用いる、VR の 
設計空間のモデルを示す。前節では状況論的視点から捉える設計行 為について述べたが、VR においては空間の広さや空間内のあらゆ る要素の大きさを一定の精度で暗黙的に捉え、身体的に空間を認識 できることが既往研究の中でも明らかにされてきている。寸法に関 わるものに限らず、空間要素の素材やテクスチャ、空間内のシーク エンスや空間同士の関係、空間が持つ雾囲気や佇まいなど、設計主 体がVR 空間の中で無意識のうちに感じ取る情報は多岐に渡る。設 計プロセスの各場面で、設計主体が認識する対象の背景にはそうい った無意識に捉えられる暗黙的な情報が存在するのであるが、本研 究ではそれらを総じて「状況」(situation) と呼ぶこととする。

ここでそれ自体における体験が設計対象の空間における体験と近 似されるVRの「設計空間」(design space)に、「主体」(subject) と 上記の「状況」、対象」(object)を位置づけて図式化したものを Fig.1 に示す。本稿ではこれをVR の設計空間のモデルとすることで、設 計主体が設計対象や他の設計主体と対話する状況を記述し、その分 析を行う。ただしこのモデルの「対象」には、壁や柱といった設計 対象の部分ないしは要素となる物体や、後述する今回構築するッー ルを用いて設計主体が生成するボックス等に限らず、和室や庭とい った空間や空間同士の関係といった概念の次元のものも含めること とする。また「状況」については 2.2 節でその概念について述べた 通り、その内容すべてを特定して明示的に記述することは原理的に 困難であり、ここでは記述自体を目的とするのではなく、読み取り が可能な限りにおいてその記述を行い、設計プロセスを分析する際 の手立てとしてそれを利用することを本モデルの前提としている。

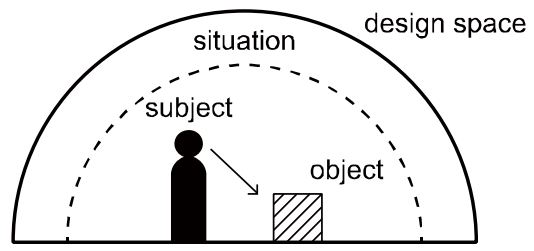

Fig.1 design space in VR

\section{VR 空間における対話による設計のためのシステムの構築}

2 章で整理した理論的枠組にもとづき、以下に示す機能を重視し ながら、VRによる設計システムを構築した。

\section{1) 複数人で共有されるVR 空間への没入}

実空間に近い感覚のもとで、空間内を移動したり、首を動かして 周囲を見まわしたりすることができる。

\section{2) 簡単なコントローラ操作によるボックスのモデリング}

Oculus Go に付属するコントローラの操作により、寸法の入力等 をすることなく自由な形状や大きさのボックスを瞬時に生成できる。 3) 生成されたボックスの編集

2)の機能で生成されたボックスを選択し、同じくコントローラの 操作でそれを移動したり色を変えたりすることができる。

以降、上記の機能の実装に向けて、ハードウェアの構成やアプリ ケーションの実装について述べていく。

\section{1 ハードウェアの構成}

まずはサーバー機となる PC 上に後述する設計ツールのアプリケ ーションを起動し、そこにネットワークを経由してクライアント機 (今回はサーバー機 1 台、クライアント機 2 台の計 3 台を実験で用

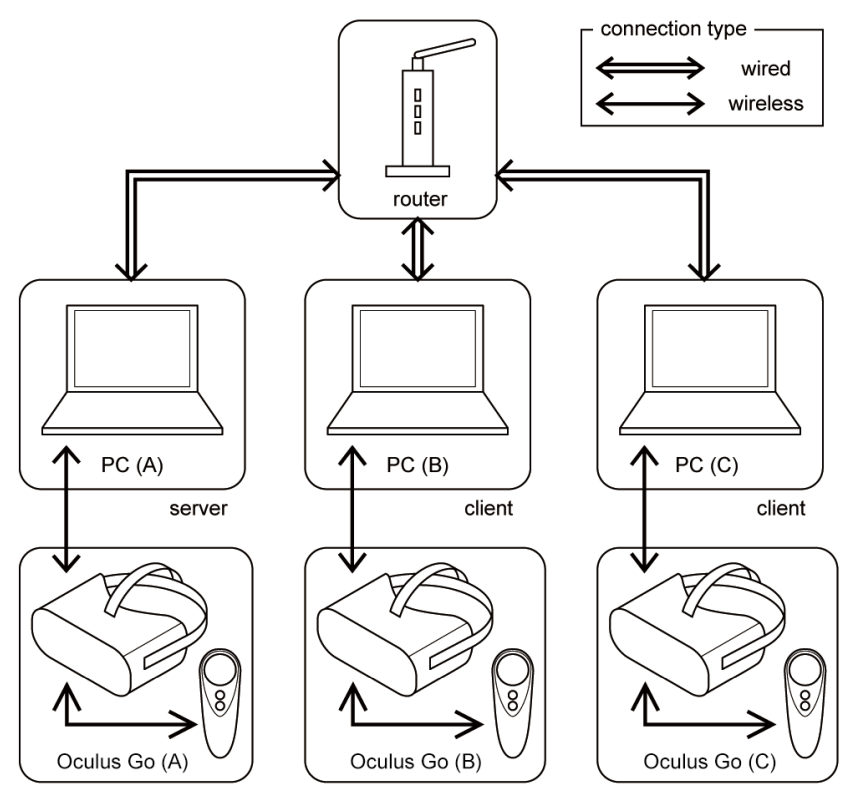

Fig.2 Hardware configuration

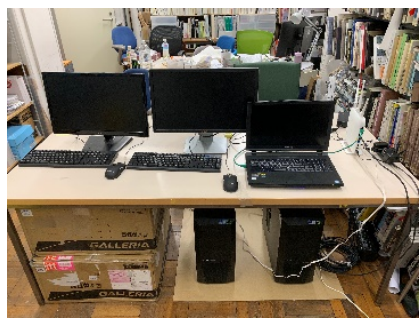

Fig.3 Hardware for experiment

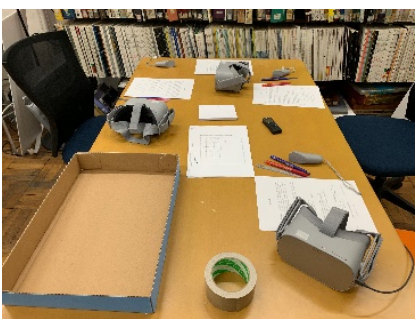

Fig.4 Oculus Go
いた。）がアクセスすることで、同じVR 空間内に複数人が共存する ことができる。そして各 PCに Oculus Go をそれぞれWi-Fi を経由 して接続することでVR 空間に没入できる。また Oculus Go を外し た状態でもVR 空間を確認できるようにするため、各 PC のモニタ 一に Oculus Go で表示されている映像をミラーリングさせた。

\section{2 アプリケーションの実装}

3.2 .1 使用したソフトウェアとテンプレート

本研究では、そのモデリング機能の性能の高さゆえに建築設計の 場でも用いられることが多い DCCッール注2)である Rhinoceros と、 ゲームエンジン注 3)である UE4 を連携し、ブループリントと呼ばれ るビジュアルスクリプティングシステム注4)を用いて（Fig.5）VR 空 間を体験できるシステムを構築した。Oculus Go のコントローラの 3 種類の入力（Fig.6）を用いて各機能を構成していく。

UE4 には目的や用途に合わせて、開発の助けとなる豊富なテンプ レートが用意されている。本研究では、その中でも「Multi-User Viewer Template(以降、MUVT)」注5) という、複数人数でのプレイ を目的としたテンプレートを使用した。MUVTでは、VR 機材での アプリケーション起動や、ローカルネットワークを利用した複数の

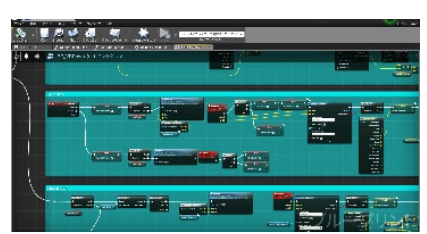

Fig. 5 Visual scripting by blueprint
Fig. 6 Input of controller

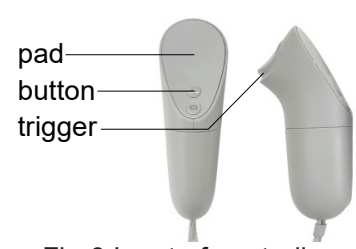


PC を接続したマルチユーザーによるプレイ機能が標準で実装され ている。また、後述する「移動」のためのテレポート機能や各プレ イヤーのアバター表示機能も実装されている。本研究ではこのテン プレートをもとに、適宜標準の機能を改良しながら、必要な機能を 追加していくことで目的のッールを実装する。

\section{2 .2 各機能の実装}

コントローラからのインプットはトリガー、パッド、ボタンの三 種類で、それらの組み合わせによって必要な各機能を実装した。以 下、インプットとそ机に対する処理、最終的なアウトプットについ て記述していく。

\section{1）自身の移動}

パッドを押す入力により、移動場所の探索が開始され、パッドを 離す入力により移動場所が確定する。確定後は自動的にカメラの移 動が実行され、瞬時に目的の場所へと移動が完了する。この機能の 大枠は MUVT で実装されており、本研究ではパッドからの入力に この機能を紐づける編集を加えた。

2）ボックスの生成

ボタンを押した瞬間にカーソルが当たる位置を一つ目の参照点と して得る。ボタンを押している間は二つ目の参照点を探索し、離す と確定してボックスの底面が決定される。次にボックスの高さを決 定するため、コントローラの動きに合わせて三つ目の参照点を探索 し、再びボタンを押すことで確定し、ボックスの生成が完了する。

\section{3）ボックスの編集}

カーソルがボックス上にあるときにトリガーを押すことでボック スの編集状態に遷移し、移動バーやカラーパレットといった UI が ポップアップする。移動バーにカーソルを合わせた状態でトリガー を押している間はボックスを移動することができ、離すとボックス はその位置で停止する。また、カラーパレット上でトリガーを押す とボックスの色が変化しはじめ、トリガーを離すと確定する。

\section{4. 構築したツールを用いた設計実験の実施}

\section{1 設計実験の概要}

前章で構築した設計ツールを用いることで、どのような設計プロ セスが展開されるのかを検証するため、建築をはじめとする設計に 関する専門的な経験を持たない人を対象とした設計実験を 2 組(以 降、各実験を実験 1、実験 2 とする)行った。実験 1 の様子を Fig.7 に、実験の概要を Table 1 に示す。

\section{2 設計実験の手順}

本研究における設計実験では、問題設定を行う設計の初期のプロ セスを観察するため、設計対象の利用方法を考元ることも課題の一 部とした。また、3)で設計案のまとめをする段階を明確に設定する ことで、2)の設計ワークショップでは問題の設定から解決までのサ イクルを自由に発想しながら繰り返せるよう意図した。

\section{1）課題を共有しデモプレイによってッールに慣れる}

Table1 に示す課題の対象となる民家の居住者は、居住用に使用し ている部屋以外の空間を知人や周辺地域の人々が自由な目的で使え るレンタルスペースとして開放している。本実験ではまず、そうし た課題の前提条件等を共有し、被験者らにはこの居住者の知人、あ るいは周辺住民として設計に取り組む想定で空間の活用方法を考元 てもらうこと、その後に設計案をまとめる段階をとること等、実験

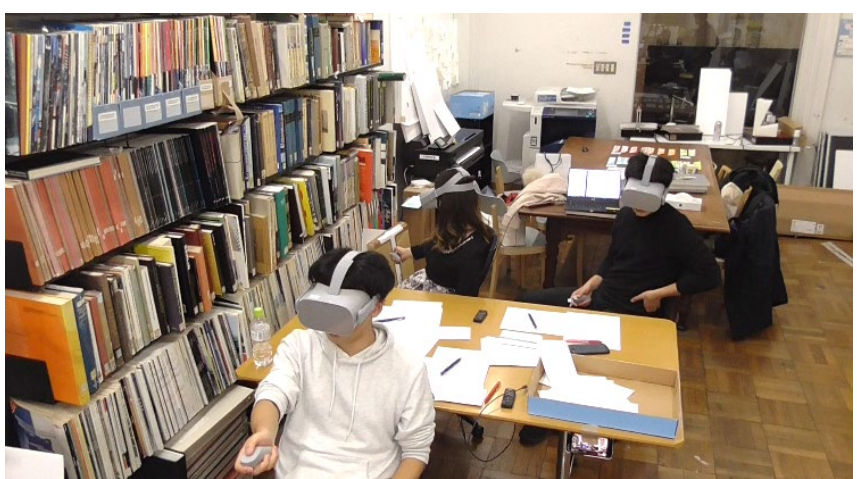

Fig.7 Experiment scene

Table 1 Summary of design experiment

\begin{tabular}{|c|c|}
\hline & $\begin{array}{c}\text { 建築設計の教育や実務経験のない者 } 6 \text { 名 } \\
\qquad 3 \text { 名 }(A, B, C) \times 2 \text { グループ(実験 1, 実験 } 2)> \\
6 \text { people who have no architectural education or practical experience. } \\
<3 \text { people(A, B and } \mathrm{C}) \times 2 \text { groups(Experiment1, Experiment2) }>\end{array}$ \\
\hline \multirow{2}{*}{$\begin{array}{l}\text { 設計課題 } \\
\text { task }\end{array}$} & $\begin{array}{l}\frac{\text { 民家の利用方法と改修案を考える }}{\text { 実在する民家を題材に、フリースペースの利用方法やそれに伴 }} \\
\text { う改修案を自由に発想する。 }\end{array}$ \\
\hline & $\begin{array}{l}\text { Consider how to use a house and renovation plans } \\
\text { Using a house as a theme, subjects freely think about how to use the free } \\
\text { space and the renovation plans. }\end{array}$ \\
\hline $\begin{array}{l}\text { 時間 } \\
\text { time table }\end{array}$ & $\begin{array}{l}\text { 1) 課題共有・デモプレイ task sharing, demo play (10min) } \\
\text { 2) 設計ワークショップ design workshop (50min) } \\
\text { 3) 設計案のまとめ wrapping up design proposal (10min) } \\
\text { 4) インタビュー interview (20min) }\end{array}$ \\
\hline $\begin{array}{l}\text { 制作物 } \\
\text { output }\end{array}$ & $\begin{array}{l}\text { アイデアカード(提案の記述やスケッチ) idea card(words or sketch) } \\
\text { 1/100 平面図(提案の記述やスケッチ) } 1 / 100 \text { plan(words or sketch) }\end{array}$ \\
\hline $\begin{array}{l}\text { 記録 } \\
\text { record }\end{array}$ & $\begin{array}{l}\text { IC レコーダー、ビデオカメラ、VR 空間の動画キャプチャー } \\
\text { IC recorder, video camera, video capture of VR space }\end{array}$ \\
\hline
\end{tabular}

の進め方について説明し、その内容を確認した。

その後、各チームの被験者 3 名には Oculus Go を装着して実際に VR 空間を体験してもらいながら、ツールの操作や VR 空間に慣れ るためのデモプレイを行った。

2）VR 空間を活用し設計対象の利用方法や改修案を考える

1)で課題の内容を共有し、ツールの操作やVR 空間に慣れた状態 で、各チーム被験者 3 名による設計ワークショップを行ってもらっ た。適宜、枚数制限の無いアイデアカードや被験者毎に配った平面 図を用いて思いついたアイデアをかきとめながら、VR 空間での対 話を通して設計対象の利用方法や改修案について議論してもらった。 ここで、実験中の VR 空間における設計行為の様子を Fig.8 に、記 録されたアイデアカードの例を Fig.9 に示す。
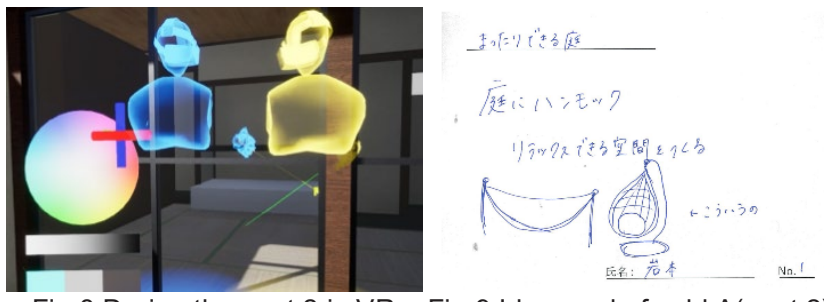

Fig.8 During the expt.2 in VR Fig.9 Idea card of subj.A(expt.2)

\section{3）VR 空間を活用し設計対象の利用方法や改修案を考える}

2)の設計ワークショップを通して考案された空間の利用方法のア イデアや改修案を一枚の平面図にまとめてもらった。ここでは、ス ケッチや図面、文字を使った記述など設計内容の表現の方法は問わ 


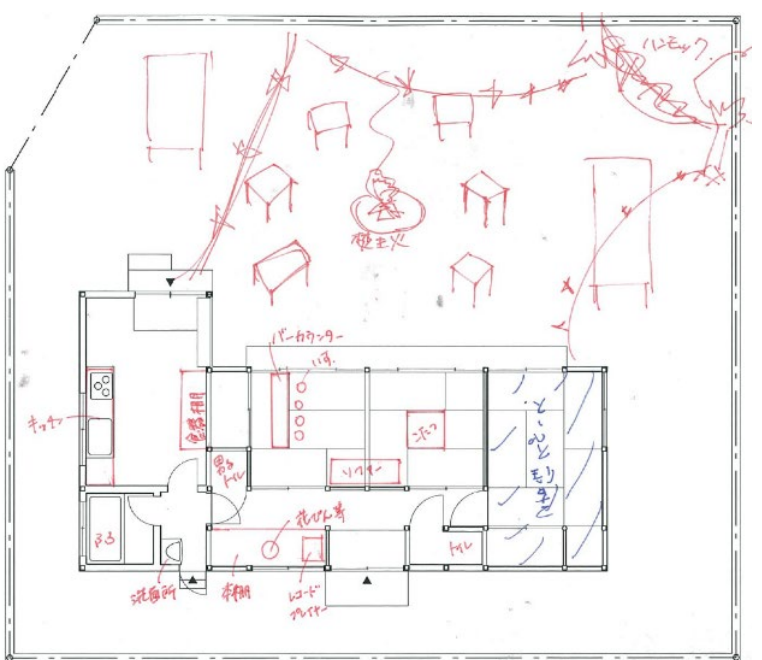

Fig.10 Summary plan of experiment 1

ず、自由にアイデアを形にしてもらった。Fig.10に最終的な提案を まとめた平面図の例を示す。

4）実験後のインタビュー

2),3）における設計プロセスの分析に加え、VR 空間の体験中の感 覚や対話ツールの機能に関する評価・感想を得るため、実験の最後 に 20 分程度のインタビューを行った。

\section{5. 設計対象との対話による設計のプロセス}

\section{1 設計対象が埋め込まれた状況の解読}

ここから設計実験で得られた記録を対象に、設計プロセスの分析 を行う。まず本節では 2 章で構築した設計空間のモデルにおける設 計の対象を取り囲む「状況」というのが具体的にどのようなもので あるのか、以下の 3 つの設計の場面を例として挙げながら確認する。

\section{1）“押し入れ”が埋め込まれた状況}

Fig.11 に実験 2 で被験者らが“押し入れ”注 6)についての議論を行 っている場面の発話を示す。また Fig.12 にはその時に被験者 C が いた場所を、Fig.13には被験者 C が“押し入れ”の方向を眺めた VR 空間内の視界の画面キャプチャーを示している。彼らはこの民家を “カフェ”として利用することを想定し、被験者 A と被験者 C は“和 室”に、被験者 B は“庭”にいながら、その“和室”の空間について議論 を進めた。まず被験者 A は“和室”に“囲炉裏”をつくることを提案す る一方でその部屋の狭さについても言及し、それに対して被験者 B は“廊下”と“和室”を隔てる“壁”を壊し、大きな空間を確保すること

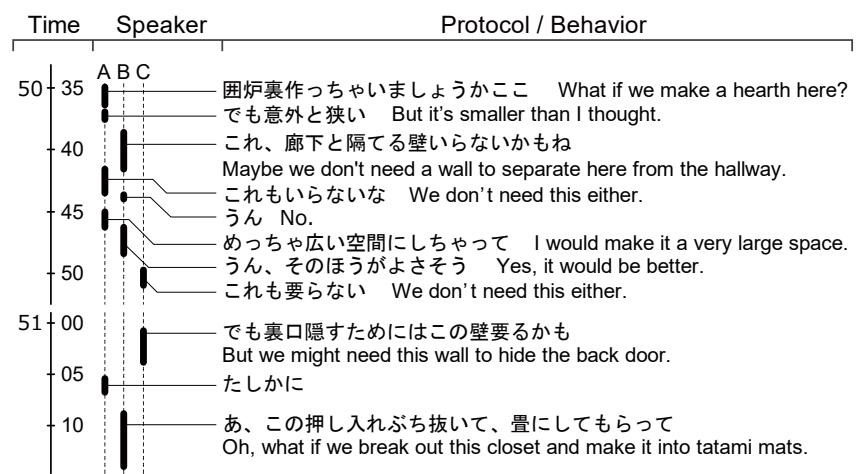

Fig.11 Discussion about the Japanese room

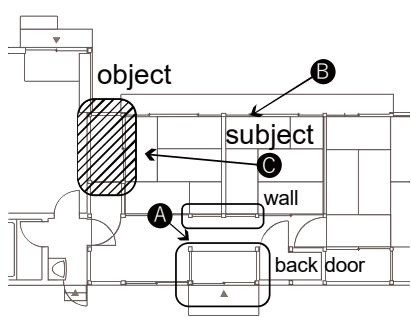

Fig.12 Position of subjects and objects

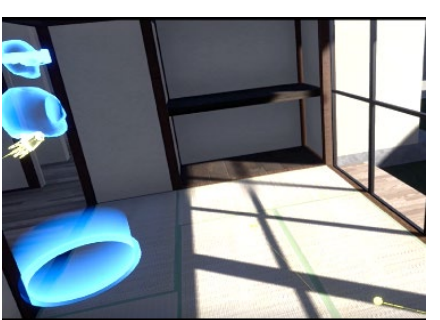

Fig.13 Scene subject $(C)$ is gazing at closet
を提案した。被験者 $\mathrm{A}$ と被験者 $\mathrm{C}$ はその意見に一度同意したが、被 験者 C は“裏口”を隠す“壁”の役割を重視し、代替案としての“和室” の“押し入れ”を壊すというアイデアの創出に至った。

最後には撤去の判断に至る“押し入れ”を中心にこのプロセスを眺 めると、“和室”の広さの把握や“廊下”との間の“壁”や“裏口”の存在へ の気付き等、“押し入れ”を取り囲む多くの要素が“押し入れ”の認識 に強く結びつき、状況を形成していると見ることができるだろう。

2)“庭”が埋め込まれた状況

Fig.14には実験 2 で“民家”の“庭”について、その空間の中にいな がら被験者らが議論している場面の発話を示す。この場面までには “民泊”のための空間を“庭”に増築する案や“菜園”等を設置する案が 出ていたが、ここでは被験者 $\mathrm{A}$ が“公園”という用途を提案した。そ れに対して被験者 B は即座に“遊具”の設置、具体的には“すべりだ い”を作るというアイデアを加えた（Fig.15、Fig.16）。

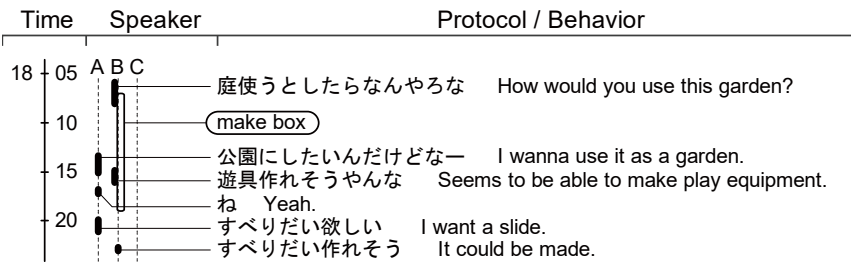

Fig.14 Discussion about the use of the garden

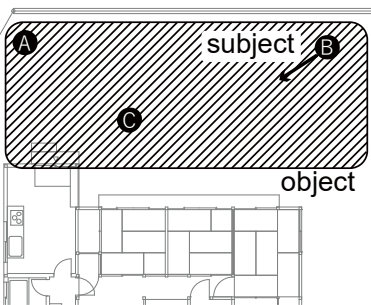

Fig. 15 Position of subject and object

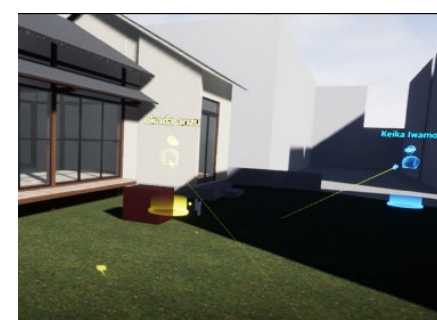

Fig.16 Scene subject(B) is talking about the yard
ここでは“遊具”の設置に関わる“庭”の広さや“地面”の素材等が、 “庭”の認識に関わる状況を形成していると見ることができ、対象の 外側の要素だけでなく、自身がその空間に身を置きながら捉えた対 象の内側の要素もその状況の形成に影響を与えていることがわかる。 3）“ボックス”が埋め込まれた状況

実験 2 の別の場面で、被験者 B はこの民家を“民泊”として活用す ることを考元、そのための“風呂”や“キッチン”を増設することを提 案した(Fig.17)。被験者 B はその後、“風呂”や“キッチン”の空間に見 
立てたボックスを既存の民家に隣接するように生成したのであるが (Fig.18、Fig.19)、このとき生成するボックスの大きさを比較する対 象として捉える民家のボリュームや、ボックスと民家のつながり方 等、もとの空間を眺めるだけでは得られなかった諸条件が捉えられ ており、操作の対象である “ボックス”に関する検討のプロセスの背 景として、それを生成する被験者の行為に強く結びついた動的な状 況の在り方を確認することができるだろう。

\begin{tabular}{|c|c|c|}
\hline Time & Speaker & Protocol / Behavior \\
\hline $11+10$ & & \\
\hline-15 & & $\begin{array}{l}\text { We can add a bath and kitchen, and make it like an inn, right? } \\
\text { 民泊? Vacation Rental? } \\
\text { 作々うそjそj Yes, like that. } \\
\text { 民泊ありだよね、私も思った That's good. I thought so, too. }\end{array}$ \\
\hline
\end{tabular}

Fig.17 Discussion about the use of the garden

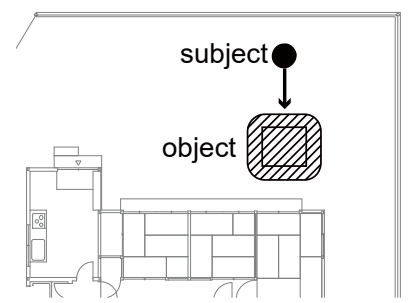

Fig.18 Position of subject(B) and object

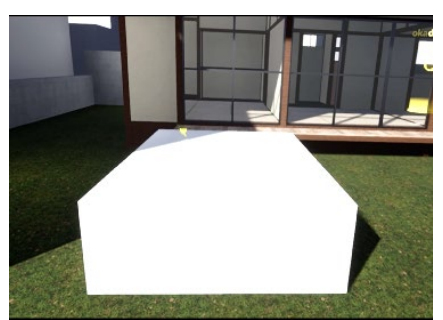
gazing at the box
Fig.19 Scene subject(B) is

\section{2 状況との対話のプロセス}

2 章で述べた状況論的アプローチの考えに沿えば、設計の対象を それが埋め込まれた状況のもとで認識することは、対象をより多角 的な視点から柔軟に捉える可能性を拡げることに繋がるものと思わ れる注7)。ここではVR 空間の中で被験者らが対象を認識する際の背 景にある状況が設計プロセスに及ぼす影響について考察する。

本研究ではVR 空間の中でコントローラの操作により自由にボッ クスを生成・編集する機能を実装したが、実験後のインタビューで その機能に関連した感想が得られた。例えば、Fig.20に示す実験 1 のインタビューを見てみると、“仕切り”や“バーカウンター”、“棚” と いった対象を被験者自らが生成し、それに対して“狭い”、“邪魔だ” というような評価をしていたことが言及されており、ボックスの生 成とそのあとの評価が連動して展開されている様子が窥える。

\begin{tabular}{|c|c|}
\hline Speaker & Protocol \\
\hline I & $\begin{array}{l}\text { ․ } \\
\text { ッール自体というか、VR 体験自体はどうだったかなというのを聞きたくて。 } \\
\text { I want to ask how was the tool and the VR experience itself. }\end{array}$ \\
\hline B & 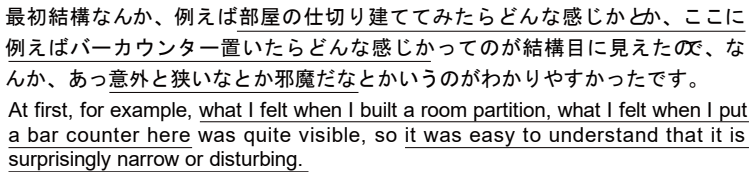 \\
\hline
\end{tabular}

Fig.20 Interview after the experiment 1

ここで、実験 1 のインタビューで言及されていた、“バーカウンタ 一”を生成・評価する場面 (Fig.21) の発話プロトコルを Fig.22に示 す。被験者 A は“バーカウンター”の設置を検討する中でボックスを 生成し、その位置や大きさ等を吟味した後に、最終的にボックスを
削除するという流れで検討を進めた。こでは生成されだバーカウ ンター”が位置する “和室”の大きさや動線等の情報に加え、“バーカ ウンター”の向きや大きさ、それが“和室”の真ん中に位置しているこ と等に鑑みでバーカウンター”が邪魔だと評価していることが窥え る。すなわち、それまでにはなかった“バーカウンター”という対象 がボックスとして生成され、そのボックスに関わるあらゆる要素が その状況を変化させ、瞬時に更新された新しい状況の中で対象を評 価していることがわかる。

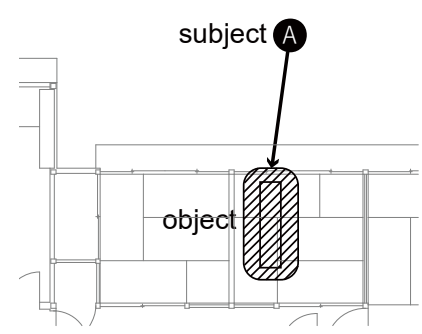

Fig.21 Position of Subject(A) and object (bar counter)

Protocol
Time

Fig.22 Process considering about the "bar counter"

同様に別の事例を対象にこうしたボックスの生成を通して設計 対象の検討を進めるプロセスを分析してみる。Fig.23には実験 2 の 中で、この“民家”を“陶芸”の体験ができるような場所とする案につ いての議論が行われている場面の発話プロトコルを示す。

ここでは“陶芸”の製作作業に必要な“窯”や“陶芸”体験をしに車で 訪れる人たちのための “駐車場”の必要性についての話題があがっ ていた。その後被験者 B は既存建物の“縁側”に立ち、“庭”の十分な 広さや既存建物の大きさを認識しながら、“陶芸”の作業スペースと してぞれくらいの大きさが必要なのか、ボックスの生成と削除を通 して検討している(Fig.24 (1)(2))。その後、被験者 B は“駐車場”につ いての話題を出しはじめ、“車”に見たてたボックスの生成と削除を 繰り返した(Fig.24 (3)(4))。この過程で被験者 B が初めに造ったボッ クスは一般的な車よりも明らかに大きく、被験者 B はすぐにそのこ とに気づいてそ扎をさくつくり直しており、ボックスの編集作業 を通して“車”の大きさの調節ができていることがわかる。またその 後、生成したボックスの位置を“庭”の中で調整しており、“庭”への “車”の入り口の位置やアプローチの仕方などの状況を踏まえつつ、 “車”の駐車位置についても検討していることがわかる(Fig.24 (5)6)。 


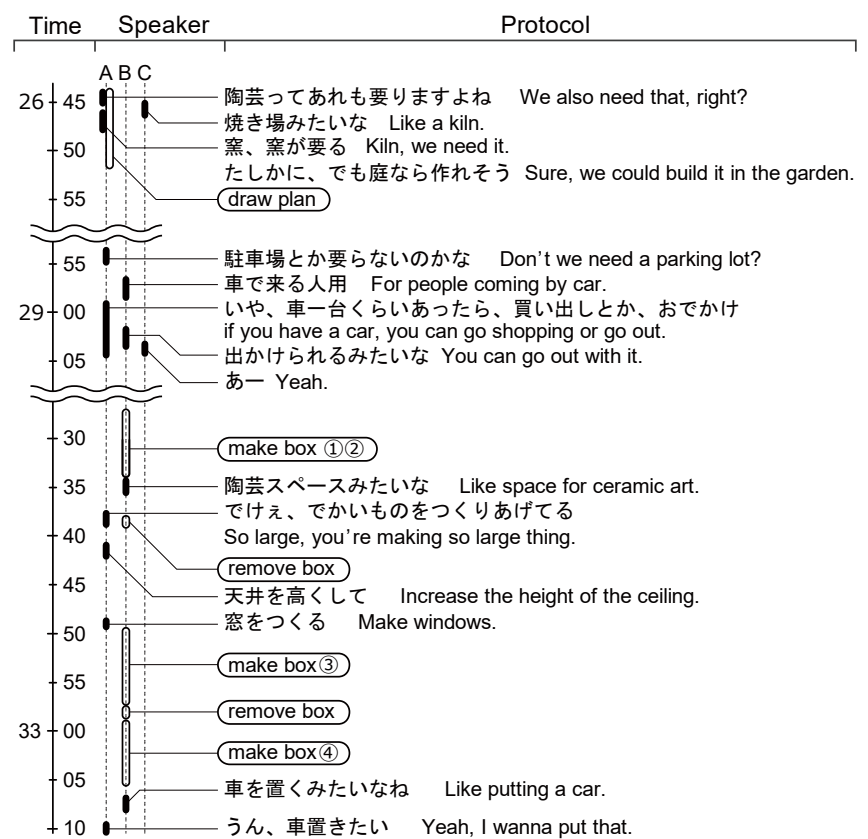

Fig.23 Discussion about a kiln and a car(expt.2)
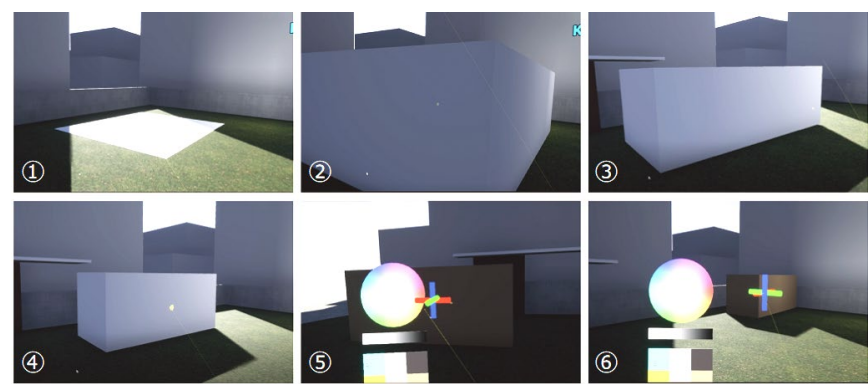

Fig.24 Scene subject(B) making a kiln and cars(expt.2)

このようにして、“陶芸”のためのスペースや“車”にみたてたボッ クスを即興的に作成し、“庭”や既存建物との関係性をはじめとする 諸要素からなる新しい状況を瞬時に捉え、更なる操作をボックスに 加えながらより良い対象の在り方を探っているプロセスを確認する ことができる。

これらの事例の分析からわかるように、被験者らはボックスの生 成や削除、編集を繰り返して試行錯誤を行う制作のプロセスを通し て設計の対象やその状況を捉えることができているのであり、対象 をつくることとそれを認識し、あるべき対象について考光ることが 密接に結びついた行為注 8)、いわばつくりながら考えるプロセスとし ての設計の可能性をここに見ることができる。このような設計プロ セスの特徵はVR の性質に依るものであると考元られる。つまりVR 空間ではその読解に一定の専門性が必要な図面や模型等の道具を介 さずに、設計対象の大きさや広さ、空間構成などを身体的な感覚の 下で直接認識することができ、さらにそれがバーチャルな空間にあ ることから、大きなコストをかけることなく制作行為を行うことが できるのであり、このようなつくりながら考えるプロセスが展開さ れる設計空間としてのVRの可能性を見出すことができるだろう。

\section{6. 他の設計主体との対話による設計プロセス}

前章では、VR 空間における設計対象が埋め込まれた状況を捉え ることによって可能となるつくりながら考えるプロセスとしての設
計について考察したが、ここでは複数の設計主体によって行われる 設計プロセスにおいて彼らが状況を共有しながら、各々の視点から 設計対象を捉えることでどのように互いの対話を重ねていくことが できるのかを明らかにすることを目指す。

本研究で行った実験の中では、被験者らが対話を行いながら設計 を進めていく場面が多く観察されたが、2 章で提示したVR 空間に おける設計空間のモデルを複数の設計主体を対象とするモデルに拡 張すると、Fig.25 のように表せるだろう。すなわち他の被験者と同 じ対象についての対話を行う際に、その状況の共有の程度によって、 (1)同じ状況を共有している場合、(2)部分的に状況を共有している場 合、(3)全く状況を共有しない場合、の 3 つの対話のパターンに整理 することができる。以降、各パターンにおいて対象が埋め込まれた 状況がどのようにVR 空間における被験者間の対話を媒介している か、そしてその状態が設計プロセスにどのような影響を与えている かを考察していく注9)。

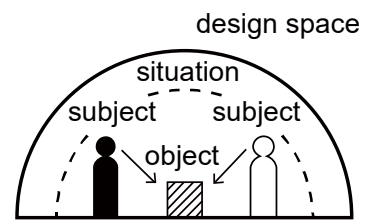

(1) same situation and same object

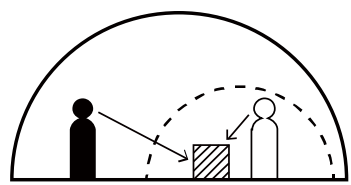

(3) different situation and same object

\section{1 相手と同じ状況から同じ対象を捉える}

Fig.26にはFig.11 で示した実験 2 における“押し入れ”に関する議 論の続きの場面の会話を示している。これは被験者 C が“和室”の使 われ方や“押し入れ”を壊すことについて提案をした後に、被験者 $\mathrm{A}$ や被験者 B がそこに同意を示しているプロセスである。

具体的に見ていくと、まず被験者 C が“押し入れ”を壊してそこに “畳”を敷き、“和室”と一体的な空間をつくることを提案した。する

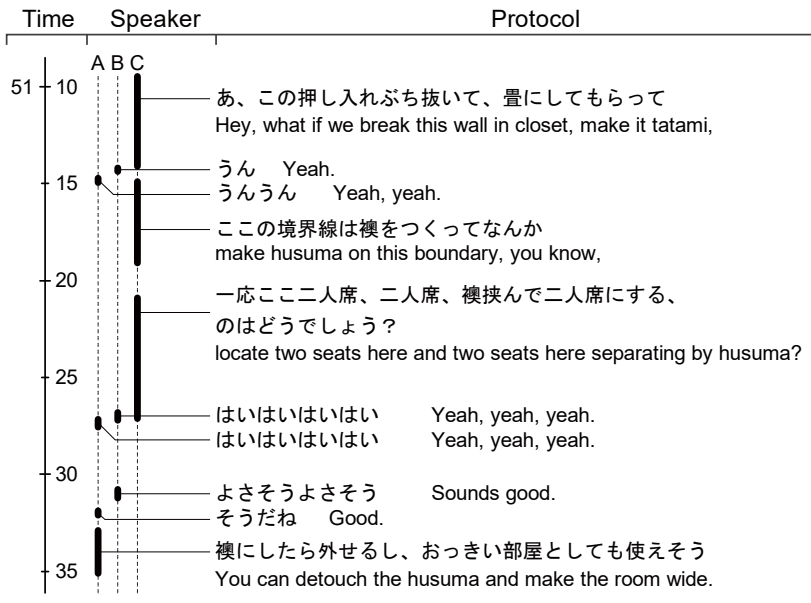

Fig.26 Discussion about the use of the Japanese room 


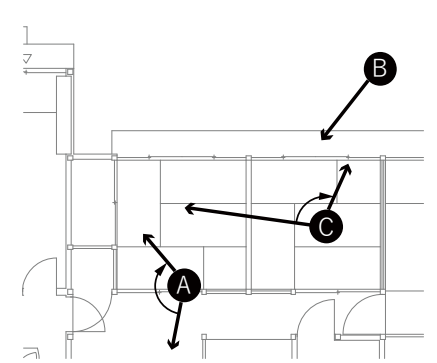

Fig.27 Position of subjects

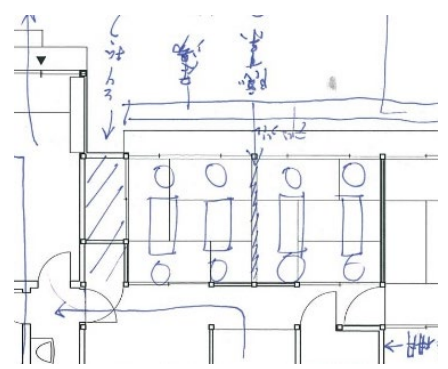

Fig.28 Plan drawn by subjects in experiment 2
とそれまで“廊下”を見ていた被験者 $\mathrm{A} は$ は和室”のほうに振り向き、 被験者 C の提案に同意した（Fig.27）。その後、被験者 C は“和室” を見渡しながら“和室”全体の真ん中を“襘”で仕切ることや、“席”の 配置の仕方等、新しい提案を更に行っていったが、被験者 $\mathrm{A}$ はこれ らの案に対しても即座に同意を示し、更には被験者 A からも用途に よって“襘”を取り外して“和室”を一体で利用する、というアイデア が出されていることがわかる。以上のような議論は被験者間で共有 され、最終的な空間利用案にも反映された(Fig.28)。

このとき被験者 $\mathrm{A}$ と被験者 C は同じ“和室”の空間内におり、空越 しに見える“庭”や“和室”につながる“廊下”の存在、床の素材である “畳”など、空間の状況の大部分を共有していたと考えることができ るだろう。この間、被験者 $\mathrm{A}$ と被験者 C との間ではそうした状況を 構成する諸要素についての直接的な言及はなかったが、Fig.26にも 多く見られる「この」や「ここ」というような指示代名詞の使用か らも確認できるように、両者の目の前に広がる対象を取り囲む状況 を共有していたからこそ、被験者間の潤滑な対話が成立していたと 考えることができるだろう。

このようにVR 空間で設計の対象が埋め込まれた状況を主体間で 共有している状態においては、暗黙のうちに共通の認識となってい る空間の情報や設計の条件に基づき、より軽微なやり取りで対象の 評価や設計の意思決定を進めていくことができると考えられる。

\section{2 相手と部分的に共有する状況から同じ対象を捉える}

6.1 節で示したような対象がおかれる状況の大部分を共有した状 態での対話がある一方で、被験者らが部分的に状況を共有する、言 い換えれば少しずれた状況の中で同じ対象を捉える場面もみられ、 ここではそのプロセスの分析を行う。

Fig.29 には実験 1 において被験者 A と被験者 B が“和室”の“壁”に ついて議論する場面の発話プロトコルを示す。ここでは、設計対象 である“民家”を“シェアハウス”にするという提案を検証するために、 はじめに被験者 B が“和室”の中に“壁”をつくった。この“壁”を対象

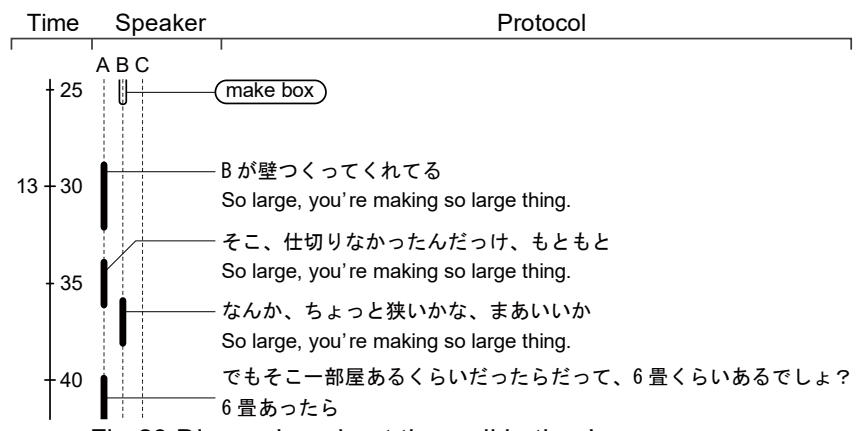

Fig.29 Discussion about the wall in the Japanese room

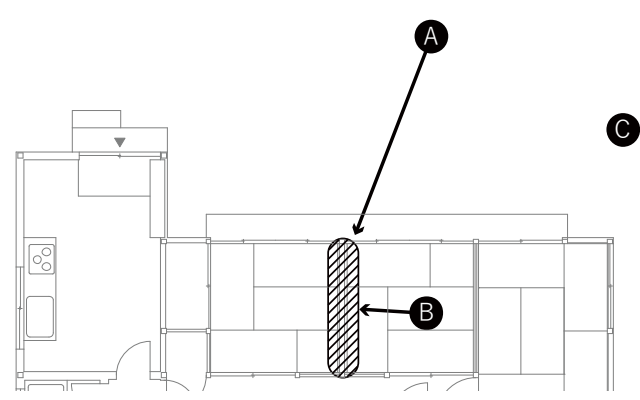

Fig.30 Position of subjects and the object

に被験者 $\mathrm{A}$ と被験者 $\mathrm{B}$ がそれぞれ評価を下すのであるが、このと き、被験者 $\mathrm{A}$ は“庭”に、被験者 $\mathrm{B}$ は“和室”の中にいた(Fig.30)。被 験者 B は“和室”の中にいながら、その“天井”の高さや“庭”への開き 方、目の前の“壁”の面積等を状況として捉えながら、“ちょっと狭い” というような空間の評価について述べた。一方で、被験者 $\mathrm{A}$ も被験 者 B と同様に“和室”や“壁”といった対象を捉えていたのであるが、 被験者 B とは異なり“庭”から“和室”を見る視点で対象を眺めてい た。このとき“庭”や“民家”全体の大きさとの比較の中で“壁”で区切 られた二つの室の広さ等を認識しており、被験者 B が捉える状況に は無い情報を含む被験者 $\mathrm{A}$ 独自の対象を取り囲む状況がそこにあっ たと考えることができるだろう。具体的な空間の広さを体感しなが ら“壁”についての判断を下している被験者 B に対して、被験者 $\mathrm{A}$ の 「6畳あったら」という発話からもわかる通り、抽象的な広さの認 識のもとで空間を捉えていることが見て取れ、そのような状況の下 で “壁”によって“和室”を仕切っても問題なく、“シェアハウス”とし てこの“和室”が“狭い”ということはないと判断した。

このように、同じ対象を捉える場合でもVR 空間において対象を 捉える状況に差異がある場合には、被験者間でその認識の仕方や評 価の基準が大きく異なってしまう可能性がある。しかし見方を変え ればこのことは、自身の目の前の状況に限らず、他の視点から捉え る対象が埋め込まれた状況をその経験主体との対話を通して共有で きる契機として捉えることもできるだろう。状況を捉えながら対象 を扱うことができたとしてもその身体的な感覚に基づくミクロな視 点からの評価や判断が時には誤った設計解を導く可能性もあり、他 の主体が上でみた事例のように離れた視点から対象を捉え、そこに 付随する異なる状況を主体間の対話を通して共有することでより総 合的に対象を捉えることができる場合も想定され、このことから VR 空間の中で各主体が同時にそれぞれの視点から捉える状況に鑑 みながらより複雑な意思決定をアドホックに重ねていくような対話 のプロセスの可能性が示唆される。

\section{3 相手と異なる状況から同じ対象を捉える}

最後に被験者間で全く状況を共有せずに同じ設計対象についての 検討を進める対話のパターンについて、ここではそのプロセスの分 析と考察を行う。

Fig.31 には実験 2 においてVR 空間で被験者 A と被験者 B が会 話している場面の発話プロトコルを示している。ここでは被験者 $\mathrm{A}$ がこの“民家”の中のある空間を発見したことから会話が始まってい る。このとき、Fig. 32 に示すように被験者 $\mathrm{A}$ と被験者 $\mathrm{B}$ は異なる場 所におり、新たに発見された空間がおかれる状況をほとんど共有し ておらず、被験者 B は直接見て確認することなく、その空間を取り 


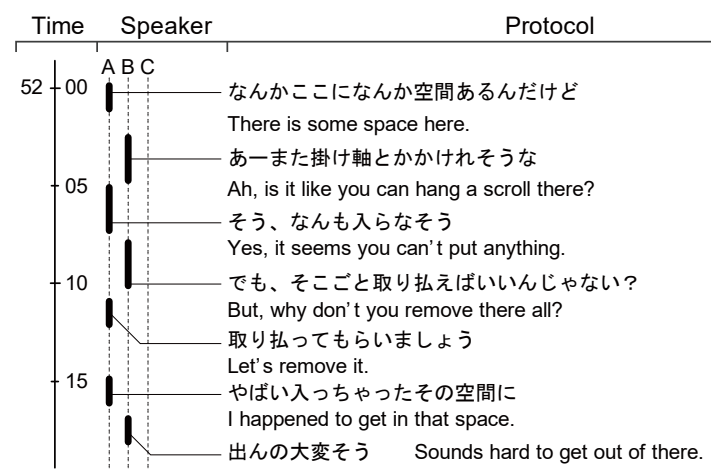

Fig.31 Discussion about the space in front of subject(A)

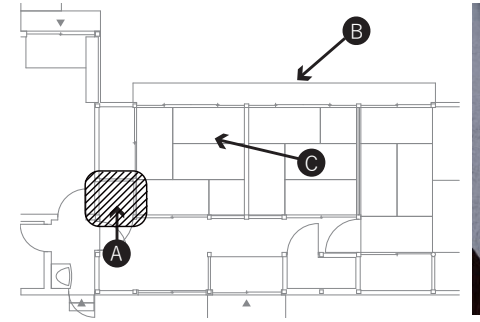

Fig.32 Position of subjects and the object

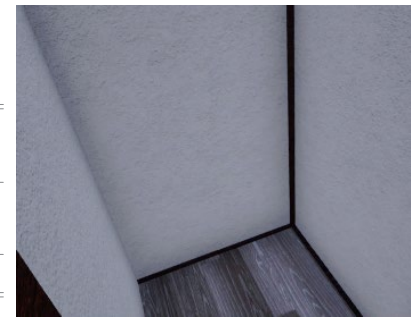

Fig.33 Scene subject(A) is gazing at the storage
払うことについての意見を述べた。ここでは被験者 B が、その空間 が“廊下”に面した単なる “収納”であるにも関わらず「掛け軸とかか けられそう」とその空間を認識していたように、被験者 $\mathrm{A}$ と同じ対 象について話しながらもその詳しい状況はほとんど正しくは捉えら れていなかったものと考元れる（Fig.33）。すなわち、ここでは複 数の主体が VR 空間内で対話を行うことの利点は上手く活かされて いなかったと考えることができるだろう。

一方で、ここまで設計空間の範囲が VR 空間に収まる事例を扱っ てきたが、その範囲を現実空間まで拡張すると、VR 空間と現実空 間で設計主体らが同じ対象を同時に評価するような設計プロセスの 可能性を見出すことができるだろう。すなわち、ある設計主体が VR 空間に没入し、設計対象がおかれる状況を捉えながらそれを評価し たり新たな操作を加えたりする間、他の設計主体が図面や模型など の設計ツールを用いて設計対象全体を包括的に捉えることによる設 計プロセスの展開の可能性である。

Fig.34 には実験 2 においてVR 空間にいる被験者と図面を見る被 験者が同じ対象について検討する場面の発話を示している。ここで は被験者 $\mathrm{A}$ と被験者 $\mathrm{C}$ は図面を見ながら、被験者 $\mathrm{B}$ はVR 空間に いながら会話を進めていた（Fig.35）。このとき被験者 B はVR 空間 内で自身のいる端の“和室”から中心の“和室”の方を見ており、その 視界には右手に“庭”の様子が、左手に“廊下”と中央の“和室”の様子 が少しずつ含まれている (Fig.36)。そして視線の抜けや隣の“和室” との関係性を状況として捉える中で目の前の“壁”を必要ないものと 評価し、「壁なくしてもいいやんな」と他の被験者に問いかけた。被 験者 $\mathrm{A}$ と被験者 $\mathrm{C}$ は被験者 $\mathrm{B}$ の問いかけを受け、図面を見ながら 被験者 C が提示した“壁”をなくすという案に同意している。続けて、 被験者 A は図面上で二つの“和室”を隔てる “壁”を波線で消した (Fig.37 に示すように後の議論でこの“壁”は残されることになり、波 線も消されている)。さらに、被験者 $\mathrm{A}$ と被験者 $\mathrm{C}$ は、被験者 $\mathrm{B}$ が 認識している“壁”とは異なる、“廊下”と“和室”を隔てる“壁”等にも言

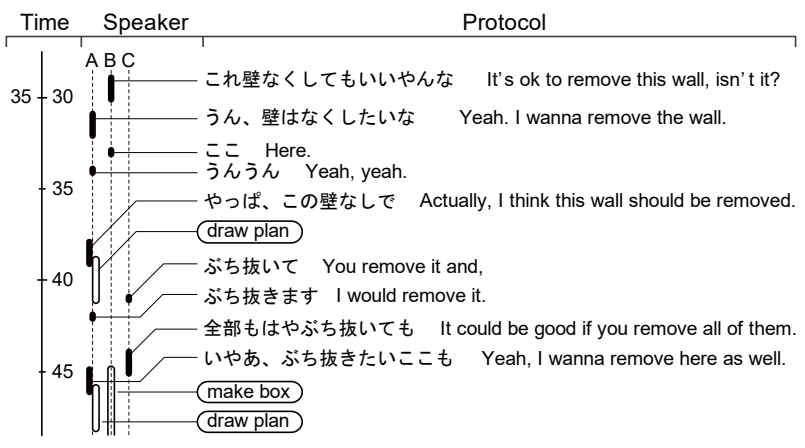

Fig.34 Process breaking the walls in the house

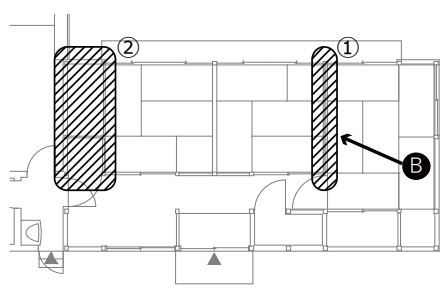

Fig.35 Position of subject(C) and the objects

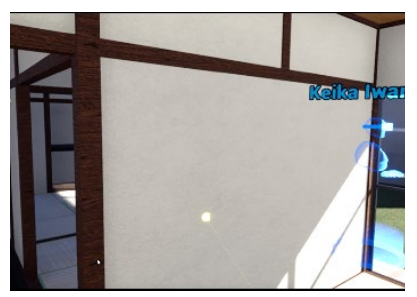

Fig.36 Scene subject(B) is gazing at the wall

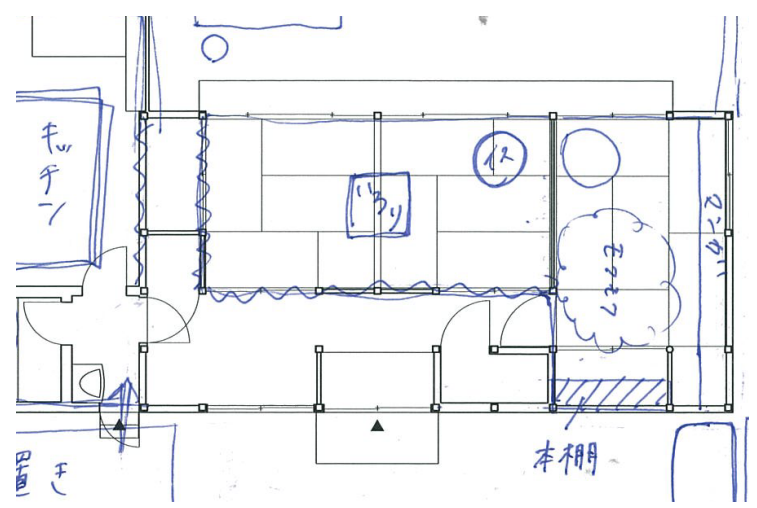

Fig.37 Plan drawn by subject(A) in experiment2

及し、それらも必要のないものであると判断し、ここでも被験者 $\mathrm{A}$ は図面上でその“壁”を波線で消した。ここでは被験者 B の VR 空間 における直接的な体験を契機に、ある “壁”を除去することが検討事 項として浮かび上がり、その後図面というフィジカルな設計ツール を通して対象全体が眺められ、他の“壁”の必要性についても検討の 目が向けられたのであるが、このような状況を介した対象の把握と 状況を介さない対象の把握が連続的に展開される、それぞれの対象 の捉え方の特長が相乗的に活かされたプロセスをこの事例で確認す ることができるだろう。

\section{7. 結論}

本稿ではまず、対話による設計のための VR を用いた設計空間の システムを構築した。次に構築したシステムを利用した設計実験を 行い、そのプロセスを記録した。設計実験では庭のある民家を対象 としてその活用方法や改修案を考案するワークショップに取り組ん でもらったが、本論では特に認知科学における状況論的アプローチ を参照しつつ、設計対象が埋め込まれた状況の在り方に着目しなが ら、VR 空間における設計主体と設計対象との対話のプロセスの分 析を行った。その結果、VR 空間において設計主体が目の前の対象 
をそれが埋め込まれた状況と一体的に捉えることによって、対象を より多角的に検討できることを示し、VR 空間内でボックスを生成 したり編集したりしながら対象についての検討を行う「つくりなが ら考える」プロセスの具体的な内容を明らかにした。

次に、VR 空間における複数の設計主体の対話のプロセスに着目 し、設計対象が埋め込まれた状況がどの程度主体間で共有されてい るかによって3つのパターンの設計空間のモデルを設定した。それ ぞれのモデルに基づいて設計実験の事例の分析と考察を行った結果、 VR 空間において設計主体間で状況を共有している場合は、より簡 易なコミュニケーションで設計に関わる諸条件を把握し、その検討 を進めることができること、状況が部分的に共有されている場合は、 異なる状況のもとで多角的に対象を捉えながら複雑な意思決定を重 ねていくことができるということを示した。さらに状況が主体間で ほとんど共有されていない場合、特に一方の設計者が状況に基づい て対象を捉え、他の設計者は状況とは切り離して対象を捉えるよう な場合も、図面等のツールを用いたフィジカルな空間まで設計空間 の範囲を拡張して捉えることで、VR を含む各ッールの利点を掛け 合わせた設計プロセスの可能性を提示した。

本稿では、設計主体と設計対象との対話や設計主体間の対話とい う観点から、設計空間としてのVR の可能性を論じてきたが、今回 構築したシステムには数多く改善の余地が残されている。例えば建 物の躯体を大きく改変するようなリノベーションを想定するのであ れば、設計対象の既存部分を編集する機能の実装も必要となるだろ う。他にも設計主体間の対話を効果的に促すためのコミュニケーシ ヨン機能をV R 空間内に実装することも検討の方針として可能性が あるだろう。今後もVR に関わる技術は更なる発展を続けることが 予想され、本研究ではそうした先端的な技術を活かした具体的な設 計ツールの開発とその検証を継続的に行うことによってVRを用い た設計空間のシステムに関わる知見を蓄積していきたい。

注

注1）スタンドアローン型HMD とはそれ単独で機能する、頭部に装着する ディスプレイ装置のことで、ディスプレイに表示される空間を体験す ることができる没入型のVR 装置である。

注2）DCC は Digital Content Creation の略称で、DCCッールとは Autodesk 社の $3 \mathrm{~d}$ s Max や McNeel 社の Rhinoceros 等、3D モデルを作成するた めのッールの事を指す。

注3）ゲーム制作において、モニターへのグラフィックの表示やコントロー ラー等からのインプットに対する動作等を実装するために必要な基本 機能を搭載したソフトウェアのこと。ゲーム制作以外にも、建築ビジ ユアライゼーションや映像分野でも用いられている。

注4）プログラミング言語を直接入力するのではなく、ボックスを線で繋ぐ ような方法で一連のアルゴリズムを作成できるシステムのこと。これ によりプログラミングの専門的な経験を持たないデザイナーやアーテ イストでもプログラムを組み、アルゴリズムを作成することが可能に なる。Rhinoceros のプラグインである Grasshopper や Revit や Maya などのソフトウェアのプラグインとして使用できる Dynamo がその一 例である。

注5） UE4 の Ver. 4.23 へのアップデート時点で廃止されており、現在は 「Multi-User Viewer Template」に新たな機能を追加した、「Collab Viewer Template」と呼ばれるテンプレートが公開されている。

注6）本稿では、被験者らが議論の中で扱う設計対象の名称等についてはダ ブルクォート (“”) で括って記すこととする。

注7）状沉と強く結びついたあるがままの設計対象に対峙することで、それ までには気付くことのなかった対象の要素や周囲との関係性を発見す ることができ、当初の想定とは異なる諸条件に触れることになり、結
果として対象を捉える多様な視点を得ることができる。

注8）デューイは、「為すことによる学び」(Learning by Doing) によって絶 えず経験を再構成することの重要性について述べたが、ここではボッ クスを操作することを通して対象やその状況を理解し、再構成された 経験が次の行動へと影響を与え、行動と学習が同時並行で進められて いることがわかる。

注9）状沉はそこに埋め込まれた対象の在り方だけでなくそれを捉える主体 の知識や経験等に依存するものであり、原理的には主体が異なれば、 それぞれの主体の目に映る状沉も異なるだろう。しかし本論で扱う状 況の概念はVR 空間内の可視的な物理要素から成るものを対象として おり、主体の位置や空間を眺める視点が同じである状態を、複数の主 体があるひとつの状沉を共有している状態として理解することとする。

\section{参考文献}

1) Fukuda, T. et al. : Capability of a distributed and synchronized discussion by using cloud computing type VR for townscape design, Journal of Architecture and Planning (Transactions of AIJ), Vol. 76, No. 670, pp.2395-2401, 2011. 12

福田知弘, 田口正晴, 清水彩子\&孫否：景観検討を対象としたクラウド コンピューティング型 VRによる分散同期型検討会議の実現可能性, 日本建築学会計画系論文集 Vol. 76, No. 670, pp.2395-2401, 2011. 12

2) Rahimian, F. P. et al. : Impacts of VR 3D sketching on novice designers' spatial cognition in collaborative conceptual architectural design, Design Studies, Vol. 32, No. 3, pp255-291, 2011. 5

3) Rieuf, V. et al. : Emotional activity in early immersive design: Sketches and moodboards in virtual reality, Design Studies, Vol. 48, pp43-75, 2017.1

4) Koutsabasis, P. et al. : On the value of Virtual Worlds for collaborative design, Design Studies, Vol. 33, No. 4, pp357-390, 2012. 7

5) Ishida, K. et al. : Influence of experience of space using VR on design process, Journal of Architecture and Planning (Transactions of AIJ), Vol. 84, No. 761, pp.1579-1587, 2019. 7

石田康平, 酒谷粋将, 田中義之, 千葉学 : VR を通した空間の経験が設 計プロセスに与える影響, 日本建築学会計画系論文集 Vol. 84, No, 761, pp.1579-1587, 2019. 7

6) Israel, J. H., et al. : Investigating three-dimensional sketching for early conceptual designdresults from expert discussions and user studies, Computers \& Graphics, Vol. 33, No. 4, pp462-473, 2009. 8

7) Alexander, C. : A Pattern Language: Towns, Buildings, Construction, Oxford Univ Press, 1977

8) Sanoff, H. : Community participation methods in design and planning, John Wiley, 2000

9) Schön, D.A. : The Reflective Practitioner - How Professionals Think in Action, Basic books, 1983

10) Monnai, T. : Design Methodology as Planning Theory of ManEnvironment System, Architectural Institute of Japan ed., Design of Man-Environment System, Shokokusha, pp.56-73, 1997 門内輝行：人間一環境系の計画理論としての設計方法論, 人間一環境 系のデザイン, 彰国社, pp.56-73, 1997

11) Suchman, L : Plans and Situated Actions The Problem of HumanMachine Communication, Cambridge University Press, 1987 


\title{
A PROCESS OF DIALOGUE WITH SITUATION IN VR AS A DESIGN SPACE
}

\author{
Shunsuke SHINOMIYA ${ }^{* 1}$, Suisho SAKATANI ${ }^{* 2}$, Yoshiyuki TANAKA ${ }^{* 3}$, \\ and Manabu CHIBA *4 \\ ${ }^{11}$ SUPPOSE DESIGN OFFICE Co., Ltd., M.Eng. \\ ${ }^{2}$ Lect., Dept. of Architecture and Environmental Design, College of Architecture and Environmental Design, Kanto Gakuin University, Dr.Eng. \\ ${ }^{3}$ Assist. Prof., Dept. of Architecture, Faculty of Engineering, The University of Tokyo, M.Env. \\ ${ }^{4}$ Prof., Dept. of Architecture, Faculty of Engineering, The University of Tokyo, M.Eng.
}

In recent years, the need to utilize vacant houses and buildings has been called for, and there are many examples of space regeneration through renovation and DIY. However, it is difficult to fully utilize the ideas for utilization of space found in the design process, and in order to expand the possibilities, it will be important for users and clients, who are the key decision makers in the construction process, to be deeply involved in the design process. On the other hand, VR(virtual reality) technology has been attracting attention in recent years, making it possible to think about design while experiencing the ever-changing design objects. It has potential to enable non-experts to become deeply involved in the design process by experiencing rich virtual images of spaces.

In this paper, we focus on the characteristics of VR, which allows the architectural space itself as the design space and aim to clarify the characteristics of design thinking by non-experts in VR environment. The purpose of this study is to understand how the process of dialogue among multiple subjects sharing the design space in VR develops.

we developed a design space system that utilizes VR technology. Specifically, we created a design tool that allows multiple subjects to experience a design target space close to real feeling, and to consider design proposals by adding various operations within that space. Next, we conducted design experiments for non-experts who do not have experience in architecture or other design fields, assuming that they are architectural users or clients, and analyze the process of dialogue between the subjects during the design process.

In this paper, "situation" refers to the implicit information that subjects can capture unconsciously in a VR space, which includes not only the dimensions, but also the materials and textures of spatial elements, the atmosphere and so on. The design space model of VR was set up by positioning the "situation", the "subject", and the "object" in the "design space" of VR. We described situations in which the subjects interact with the objects and other subjects, and analyzed the process using the model.

In the design experiment, through the workshop to devise usage and renovation plans for a private house with a garden, we analyzed in detail the interaction between the design subject and the object and the interaction between the subjects in VR space. As a result, we clarified two things as follows.

(1) Through the analysis of the situations and objects perceived by the subjects in the VR space, the possibility of a design process that is carried out by repeated evaluation and efficient iterations, that is, by "thinking while making".

(2) We extended the model of design space in VR space to include other subjects and set up three patterns of design space models mediated by "objects". When the "situation" is shared between them, we presented the possibility to minimize the discrepancy between design entities. When the "situation" is partially shared, we presented the possibility of the design process in which complex decisions are discussed from multiple perspectives between the subjects. Furthermore, when the "situation" is not shared, we presented the possibility of the design process by multiplying the advantages of each tool by extending the scope of the design space to the discussion using tools such as drawings. 